\title{
Recent advance on VOCs oxidation over layered double hydroxides derived mixed metal oxides
}

\author{
Shuangde Li a, Dongdong Wang a,b, Xiaofeng Wu a, Yunfa Chen a,c,* \\ a State Key Laboratory of Multi-phase Complex Systems, Institute of Process Engineering, Chinese Academy of Sciences, Beijing 100190, China \\ b University of Chinese Academy of Sciences, Beijing 100049, China \\ c Center for Excellence in Regional Atmospheric Environment, Institute of Urban Environment, Chinese Academy of Sciences, Xiamen 361021, Fujian, China
}

\section{A R T I C L E I N F}

\section{Article history:}

Received 29 September 2019

Accepted 1 November 2019

Published 5 April 2020

\section{Keywords:}

Volatile organic compounds oxidation

Layered double hydroxides

Mixed metal oxides

Water vapor

Oxidation mechanism

\begin{abstract}
A B S T R A C T
Catalytic oxidation is regarded as one of the most promising strategies for volatile organic compounds (VOCs) purification. Mixed metal oxides (MMOs), after topological transformation using layered double hydroxides (LDHs) as precursors, are extensively used as catalysts for VOCs oxidation due to their uniformity advantage. This review summarizes the developments in the LDH-derived VOCs heterogeneous catalytic oxidation over the last 10 years. Particularly, it addresses the VOCs abatement performance over MMO, noble metal/MMO, core-shell structured MMO, and integral MMO film catalysts originating from LDHs. Moreover, it highlights the water vapor effect and oxidation mechanism. This review indicates that LDH-based catalysts are a category of important VOCs oxidation materials.
\end{abstract}

(C) 2020, Dalian Institute of Chemical Physics, Chinese Academy of Sciences. Published by Elsevier B.V. All rights reserved.

\section{Introduction}

Volatile organic compounds (VOCs) are not only major contributors to air pollution including haze and ozone formation, but are also hazardous to human and natural life due to their malodorous, toxic, and carcinogenic nature [1-7]. Heterogeneous catalytic oxidation is recognized as one of the best VOC elimination technologies with few byproducts under relatively low operation temperatures $\left(200-450{ }^{\circ} \mathrm{C}\right)$ [8-13]. Supported noble metal and metal oxide based systems are conventionally studied as two types of VOC combustion catalysts [14-18] and are reviewed by many authors $[12,13,19,20]$. He et al. [21] reviewed recent advances in VOCs abatement based on various sorts of pollutants and their sources. Substantial efforts have been made to develop transitional metal oxides as alternatives to precious metal catalysts using layered double hydroxides (LDHs) as precursors.

LDHs are a class of anionic clay materials that consist of positively charged metal hydroxide layers and interlayer anions, such as $\mathrm{NO}_{3}{ }^{-}$and $\mathrm{CO}_{3}{ }^{2-}$, which can be expressed as $\left[\mathrm{M}_{1-x^{2+}} \mathrm{M}_{x^{3+}}(\mathrm{OH})_{2}\right]\left(\mathrm{A}^{n-}\right)_{x / n} \cdot \mathrm{mH}_{2} \mathrm{O}$ [22-26]. The structures of LDHs can be recognized as partially substituted $\mathrm{Mg}^{2+}$ cations in brucite structure $\left(\mathrm{Mg}(\mathrm{OH})_{2}\right)$ with a trivalent metal, such as $\mathrm{Al}^{3+}$. Metal cations disperse in an ordered and uniform manner in brucite-like layers [27]. The partial or total replacement of $\mathrm{Mg}^{2+}$ or $\mathrm{Al}^{3+}$ cations with $\mathrm{Zn}^{2+}, \mathrm{Ni}^{2+}, \mathrm{Cu}^{2+}, \mathrm{Co}^{2+}$ or $\mathrm{Fe}^{3+}, \mathrm{Cr}^{3+}, \mathrm{Mn}^{3+}$ can afford a wide variety of LDH materials [28-30]. LDH-based materials show good performance as photocatalysts for re-

\footnotetext{
* Corresponding author. Tel/Fax: +86-10-82544896; E-mail: yfchen@ipe.ac.cn

This work was supported by the National Key R\&D Program of China (2017YFC0211503, 2016YFC0207100), the Strategic Priority Research Program (A) of the Chinese Academy of Sciences (XDA23030300), the National Natural Science Foundation of China (21401200, 51672273), the Open Research Fund of State Key Laboratory of Multi-phase Complex Systems (MPCS-2017-D-06), and the Young Talent Project of the Center for Excellence in Regional Atmospheric Environment, CAS (CERAE201805). DOI: S1872-2067(19)63446-7 | http://www.sciencedirect.com/science/journal/18722067 | Chin. J. Catal., Vol. 41, No. 4, April 2020
} 
newable energy production [23], photoelectrochemical water splitting [31], supercapacitors [32], denitrification [33-35], $\mathrm{CO}_{2}$ capture [36,37], etc. based on their unique layered structure, compositional flexibility, and surface defect design.

The thermal treatment of these materials at specific temperatures provide a facile route to obtaining mixed metal oxides (MMO) presenting several unique properties, such as large surface areas and porosities, high thermal stabilities, and excellent metal oxides dispersion, as well as basic properties [38-41]. The synergistic effects between different metal oxides are one of the most interesting properties achieved using LDH precursors [29,42]. Recently, authors have devoted considerable attention to heterostructured interfaces by the topological transformation of LDHs due to the existing edge and corner sites with few coordinative unsaturated active sites, which will induce enhanced performance [43-45]. In the past few years, there have been several reviews based on LDH precursors and their thermal treatment involving heterogeneous catalysis for various reactions, including environmental pollution control and organic transformations [38-41]. In this review, we mainly focus on the catalytic oxidation of VOCs over LDH-derived catalysts classified under MMO catalyst, noble metal/MMO catalyst, core-shell MMO catalyst, and integral MMO catalyst within the last 10 years (Fig. 1). The effect of water vapor on the activity and catalytic mechanism are also highlighted. Expectedly, this review will attract more attention toward LDH-derived catalysts for VOCs elimination.

\section{Catalytic oxidation of VOCs over LDH-derived catalysts}

\subsection{VOC catalysts based on MMO}

Many kinds of active transition metals (e.g., Mn, Fe, Co, Ni, $\mathrm{Cu}, \mathrm{Zn}, \mathrm{Ti}$, and $\mathrm{Zr}$ ) can be incorporated into the host layer of LDHs with one, two, or more transition elements together. The calcination of these kinds of LDHs at different temperatures under air exposure mainly affords MMO in solid solution or spinel style, which would exhibit good catalytic activity toward VOCs oxidation, including benzene series, oxygen-VOCs, and CVOCs. The cation composition, metal molar ratio of the host layer, preparation method, and calcination temperature during the preparation of the LDHs precursors will influence the tex-

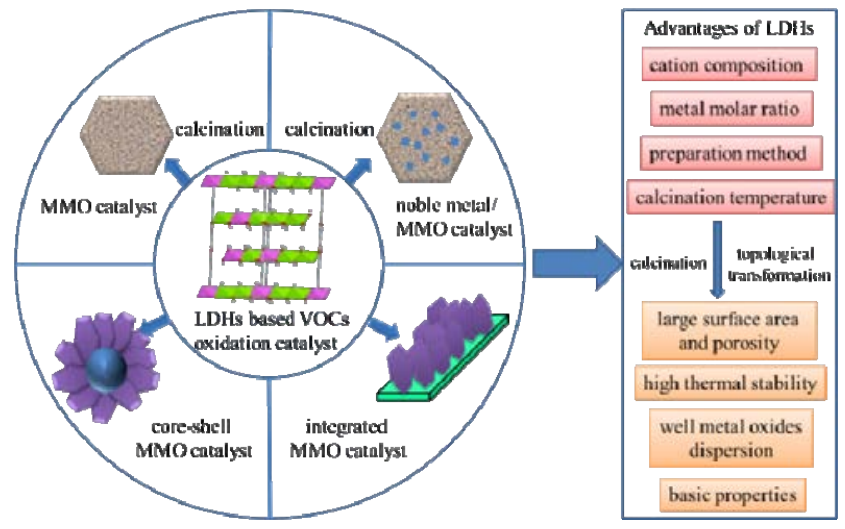

Fig. 1. Assortment and advantages of LDH-derived catalysts for the catalytic oxidation of VOCs. tural properties of the resulting catalysts, which will be anticipated to induce varied catalytic activities. Table 1 partly summarizes publications in recent years on transition metal-based catalysts for the catalytic oxidation of VOCs derived from LDH precursors.

The substitution of $\mathrm{Mg}^{2+}$ in $\mathrm{MgAl} \mathrm{LDH}$ is expected to induce distinctly different VOC oxidation performances and was systematically investigated by Genty et al. [61]. The different redox properties ascribed to the nature of bivalent cations play key roles in ensuring the catalytic efficacy. The catalytic activity toward toluene oxidation has been confirmed to be in the order of $\mathrm{Mn}_{6} \mathrm{Al}_{2} \mathrm{HT}>\mathrm{Co}_{6} \mathrm{Al}_{2} \mathrm{HT}=\mathrm{Cu}_{6} \mathrm{Al}_{2} \mathrm{HT}>\mathrm{Fe}_{6} \mathrm{Al}_{2} \mathrm{HT}>\mathrm{Ni}_{6} \mathrm{Al}_{2} \mathrm{HT}>>$ $\mathrm{Zn}_{6} \mathrm{Al}_{2} \mathrm{HT}>\mathrm{Mg}_{6} \mathrm{Al}_{2} \mathrm{HT}$ after calcination at $500^{\circ} \mathrm{C}$. It can be concluded that divalent cations play key roles in ensuring the VOC oxidation efficiency. Besides, the valence states of surface active phases, which correspond to reducibility and desirable surface exposed defects, are quite well related to the VOC oxidation activity. Mo et al. designed a $\mathrm{Co}_{2.8} \mathrm{Co}_{2} \mathrm{III}_{1} \mathrm{LDH}$ nanostructure via a facile topochemical transformation route under a dynamic oxygen atmosphere and proved that rich surface $\mathrm{Co}^{3+}$ ions are crucial for enhanced benzene/toluene oxidation performance [46]. Rich $\mathrm{Co}^{3+}$ nanocatalysts exhibited a higher catalytic activity with $99 \%$ conversation (temperature $T_{99}$ (benzene) $=210^{\circ} \mathrm{C}$ and $T_{99}$ (toluene) $=220^{\circ} \mathrm{C}$ ) than that exhibited by low levels of $\mathrm{Co}^{3+}$ based nanocatalyst from CoAlLDH prepared by a traditional coprecipitation method.

The mixed oxides normally present better performance than the individual oxide does for the cooperative effects, which induces changes in their structure and redox properties. Jiratova et al. [52] analyzed the effect of the cation composition on ethanol oxidation derived from LDHs with $\mathrm{M}^{\mathrm{II}}=\mathrm{Cu}, \mathrm{Co}, \mathrm{Ni}$, $\mathrm{CuNi}, \mathrm{CuCo}, \mathrm{CoNi}$, and $\mathrm{M}{ }^{\mathrm{III}}=\mathrm{Mn}$ or $\mathrm{Al}$ by the coprecipitation of nitrate solutions. The Mn-containing ternary mixed oxide catalysts are more active than the ternary Al-containing and the binary $\mathrm{Cu}-\mathrm{Mn}$, Co-Mn, and Ni-Mn catalysts are. The CuNiMn mixed oxide catalysts exhibit the best oxidation activity with $T_{90}=154{ }^{\circ} \mathrm{C}$. The catalytic activities are positively related to increasing the amount of easily reducible components. Li et al. [53] reported CoCuAl spinel oxides for benzene oxidation, prepared from $\mathrm{CoCuAlCO}_{3} \mathrm{LDHs}$ synthesized by the coprecipitation method, followed by calcination at $500{ }^{\circ} \mathrm{C}$. $(\mathrm{Co}, \mathrm{Cu})(\mathrm{Co}, \mathrm{Al})_{2} \mathrm{O}_{4}$ spinel with low $\mathrm{Cu}$ loading exhibits increased total conversion activity with $T_{90}=306{ }^{\circ} \mathrm{C}$ under $36000 \mathrm{~mL} \cdot \mathrm{g}^{-1} \cdot \mathrm{h}^{-1}$ due to a strong interaction between $\mathrm{Cu}^{2+}$ and $\mathrm{Co}^{3+}$ active sites; however, the activity decreases with high $\mathrm{Cu}$ loading toward the formation of bulk $\mathrm{CuO}$ separated from the spinel. $\mathrm{Cu} / \mathrm{Mn} / \mathrm{Mg} / \mathrm{Al}$ and $\mathrm{Co} / \mathrm{Mn} / \mathrm{Mg} / \mathrm{Al}$ mixed oxides were obtained following the calcination of hydrotalcite precursors. The mixed active phases from $\mathrm{Cu}-\mathrm{Mn}$ or Co-Mn will optimize the physicochemical and catalytic properties compared with the case involving only the $\mathrm{Mn}$ active phase. $\mathrm{Co} / \mathrm{Mn} / \mathrm{Mg} / \mathrm{Al}$ catalysts are the most active toward the degradation of VOCs following the order of butanol $<$ ethanol $<$ toluene, which is related to the amorphous phases and redox cycles for the cooperative effect between Co and Mn [62]. Mo observed the significant promotional effect of Ce on $\mathrm{Mn}-\mathrm{Al}$ oxide catalysts for the catalytic activity of benzene. The enhanced activity is ascribed to the electronic transfer between 
Table 1

Summary of publications in recent years on transition metal-based catalysts for the catalytic oxidation of VOCs.

\begin{tabular}{|c|c|c|c|c|c|c|}
\hline $\begin{array}{l}\text { Catalyst with calcination } \\
\text { temperature }\end{array}$ & Method & VOCs & $\begin{array}{l}\text { Space velocity } \\
\left(\mathrm{mL} \cdot \mathrm{g}^{-1} \cdot \mathrm{h}^{-1}\right)\end{array}$ & $\begin{array}{l}\text { Temperature } \\
\left({ }^{\circ} \mathrm{C}\right)\end{array}$ & $\begin{array}{c}\text { Conversion } \\
(\%)\end{array}$ & Refs. \\
\hline $\mathrm{Co}^{\mathrm{II}} \mathrm{Co}^{\mathrm{III}} \mathrm{AlO}-400$ & Coprecipitation under dynamic oxygen & 100 ppm benzene & 60000 & 210 & 99 & [46] \\
\hline $\mathrm{Co}^{\mathrm{II}} \mathrm{Co}{ }^{\mathrm{III}} \mathrm{AlO}-400$ & Coprecipitation under dynamic oxygen & 191 ppm toluene & 60000 & 220 & 99 & [46] \\
\hline $\mathrm{Ce} / \mathrm{MnAlO}-400$ & Coprecipitation-hydrothermal & 100 ppm benzene & 60000 & 210 & 90 & [47] \\
\hline $\mathrm{Cu}_{0.5} \mathrm{Co}_{2.5} \mathrm{AlO}-400$ & Coprecipitation & 100 ppm benzene & 60000 & 290 & 90 & [48] \\
\hline $\mathrm{NiCo}_{2} \mathrm{AlO}-400$ & Urea coprecipitation & 1000 ppm benzene & 60000 & 227 & 90 & [49] \\
\hline $\mathrm{CoMn}_{2} \mathrm{Al}-550$ & $\begin{array}{l}\mathrm{NH}_{4} \mathrm{OH} \text { coprecipitation-hydrothermal } \\
\text { method }\end{array}$ & 100 ppm benzene & 60000 & 208 & 90 & {$[50]$} \\
\hline 5:1CoAlO-300 & Coprecipitation & $1000 \mathrm{ppm}$ acetone & 33000 & 225 & 90 & {$[51]$} \\
\hline CuNiMnO-500 & Coprecipitation & 750 ppm ethanol & 20000 & 154 & 90 & {$[52]$} \\
\hline$(\mathrm{Co}, \mathrm{Cu})(\mathrm{Co}, \mathrm{Al})_{2} \mathrm{O}_{4}-500$ & Coprecipitation & 516 ppm benzene & 36000 & 306 & 90 & [53] \\
\hline $\mathrm{Co}_{6} \mathrm{Al}_{2} \mathrm{HTMW}-500$ & Microwaves & $1000 \mathrm{ppm}$ toluene & 60000 & 275 & 90 & {$[54]$} \\
\hline $\mathrm{MnCuAl}-450$ & Coprecipitation & 800 ppm toluene & 75000 & 297 & 100 & [55] \\
\hline $\mathrm{Co}_{3} \mathrm{O}_{4}-500$ & Coprecipitation & 1000 ppm 1,2-dichloroethane & 35294 & 300 & 90 & {$[56]$} \\
\hline CuMgAl-550 & Coprecipitation & 1000 ppm trichloroethylene & 35294 & 500 & 90 & [57] \\
\hline CuNiAl-550 & Coprecipitation & 1000 ppm trichloroethylene & 35294 & 530 & 90 & [57] \\
\hline $\mathrm{Pd} / \mathrm{Co}_{3} \mathrm{AlO}-500$ & Coprecipitation & 800 ppm toluene & 30000 & 230 & 90 & [58] \\
\hline PdCoAl-600 & $\begin{array}{l}\text { Urea hydrothermal following } \\
\text { impregnation }\end{array}$ & $1000 \mathrm{ppm}$ toluene & 60000 & 226 & 90 & [59] \\
\hline $\mathrm{Pd} 0.5 / \mathrm{Cu}(5)-\mathrm{Mg}-\mathrm{Al}-500$ & Coprecipitation following impregnation & $4 \%$ methanol & 12000 & 220 & 90 & {$[60]$} \\
\hline
\end{tabular}

$\mathrm{CeO}_{2}$ and $\mathrm{MnO}_{x}$, via a redox pathway: $\mathrm{Ce}^{4+}-\mathrm{Mn}^{3+} \leftrightarrow \mathrm{Ce}^{3+-} \mathrm{Mn}^{4+}$ [47].

Li et al. $[48,49]$ constructed a series of $\mathrm{Cu}$ or Ni doping CoA10 catalysts by the coprecipitation of their corresponding LDHs following calcination at $400^{\circ} \mathrm{C}$ and systematically evaluated the relationship of the molar ratio $(\mathrm{Cu} / \mathrm{Ni}: \mathrm{Co})$ within the host layer and their benzene abatement performances (Fig. 2). $\mathrm{Cu}_{x} \mathrm{Co}_{3-x} \mathrm{AlO}$ catalysts consist of $\mathrm{CuO}$ and $\mathrm{Co}_{3} \mathrm{O}_{4}$ mixed phases, while $\mathrm{Ni}_{x} \mathrm{Co}_{3-x} \mathrm{AlO}$ catalysts consist of $\mathrm{a} \mathrm{Co}_{3} \mathrm{O}_{4}$ phase with the absence of a $\mathrm{NiO}$ phase, revealing the formation of a solid solution. The benzene oxidation activities all exhibit volcano shapes, implying the presence of $\mathrm{Cu}$ or Ni doping. It can be concluded that the doping will induce a change in the reducibility and surface oxygen species of the catalysts through the coordination of $\mathrm{Cu} / \mathrm{Ni}$ with $\mathrm{Co}$. Zhao et al. [51] investigated the influence of $\mathrm{Co} / \mathrm{Al}$ molar ratios and the calcination temperature on acetone oxidation. The 5:1 CoAlO-300 catalyst performed efficiently in acetone oxidation with $T_{90}=225^{\circ} \mathrm{C}$. The Co/Al molar
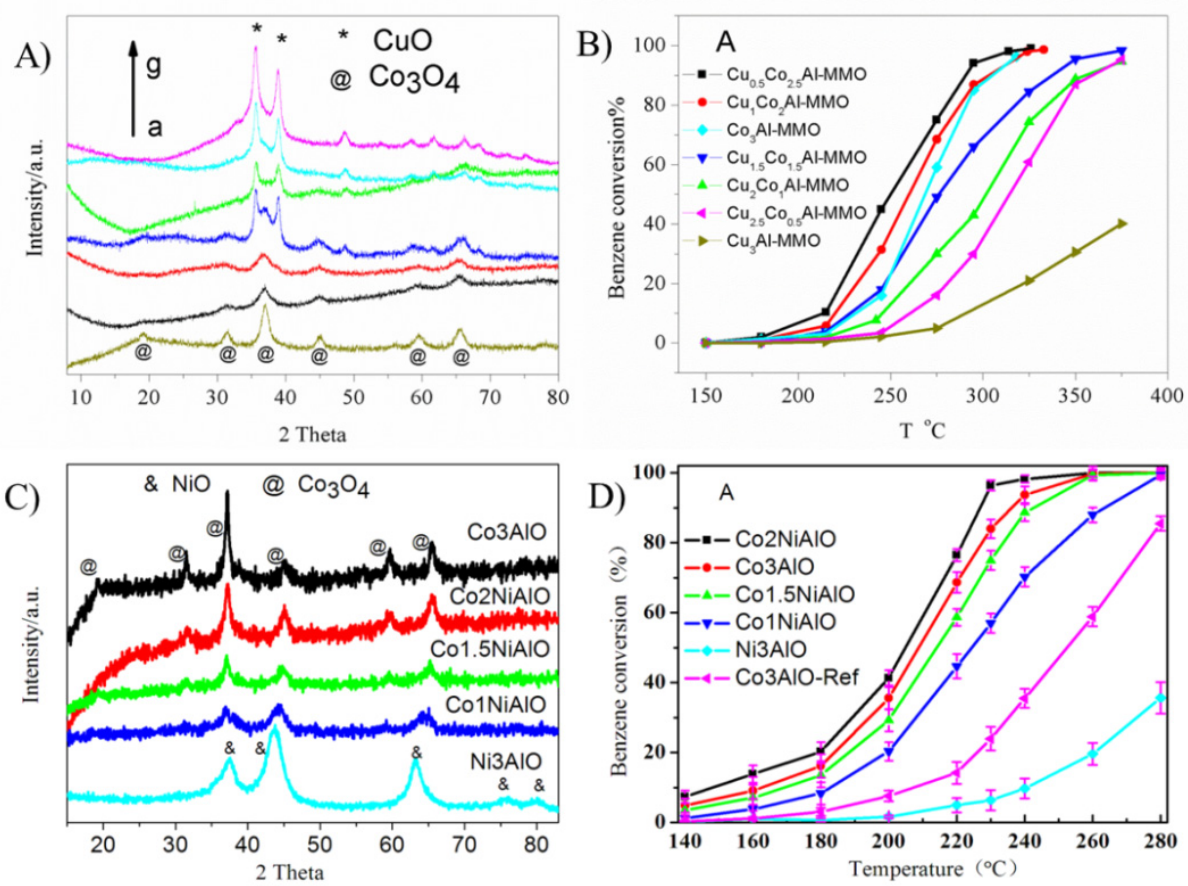

Fig. 2. (A, B) XRD patterns of CoCuAlO and benzene conversion vs temperature [48]; (C, D) XRD patterns of CoNiAlO and benzene conversion vs temperature [49]. 
ratios influence the activity by affecting the surface $\mathrm{Co}^{3+} / \mathrm{Co}^{2+}$ molar ratio and low-temperature reducibility.

Evidently, the preparation method influenced the physicochemical properties of the LDHs. The MgAl and CoAl hydrotalcite-derived catalysts were evaluated based on their activity toward toluene oxidation using co-precipitation, microwave-assisted, and ultrasound-assisted methods. Among the three sample groups, microwave-assisted catalysts, MgAlHTMW500 and CoAlHTMW500, exhibited the highest activity with $T_{90} \approx 275$ and $408{ }^{\circ} \mathrm{C}$ at $60000 \mathrm{~mL} \cdot \mathrm{g}^{-1} \cdot \mathrm{h}^{-1}$ due to the modification of the structural characteristics (surface area and morphology), together with the reducibility [54]. Actually, microwave-assisted catalysts possess larger surface areas and smaller crystallite sizes with rod morphology compared to those of co-precipitation and ultrasound-assisted catalysts. The application of Co-Mn mixed oxides for the degradation of toluene and 2-propanol with the influence of the synthesis method were also systematically characterized [42]. The existence of a cooperative effect between the Co and Mn oxides synthesized by coprecipitation, in comparison with those prepared by the auto combustion method, enhances the oxygen mobility and the redox properties of the material due to the formation of a solid solution. ${ }^{180}$ isotope exchange shows that oxygen mobility plays a more important role than the redox property does in the VOCs oxidation. Co-Mn-Mg-Al oxides synthesized by auto-combustion and co-precipitation techniques were employed to evaluate the influences of the oxygen storage capacity and oxygen mobility [63]. The cooperative effect between Co and Mn through co-precipitation will promote the redox properties and oxygen mobility, which would improve the catalytic activity for the mixture of toluene and 2-propanol.

Mo et al. [46] reported well-defined CoAlLDH precursors with different self-assembled 3D nanostructure morphologies affected by different ammonia-releasing reagents and solvents through the homogeneous co-precipitation method. The resultant catalysts show varied physical and chemical characteristics, such as acid sites distribution, acidity, surface area, and surface element composition, which were further correlated systematically to their physicochemical properties and catalytic activities. The CoAlO sample with uniform pompom-like structures, synthesized in ethanol solvent with urea as a precipitant, exhibits the best activity with $T_{99}$ (benzene) $=230{ }^{\circ} \mathrm{C}$, which is ascribed to a high number of Lewis acid sites beneficial for VOCs adsorption. Alkali doping has a positive effect on the catalytic activity by neutralizing acidic centers and modifying the surface electronic property. A K-modified CoMnAl mixed oxide catalyst $(0 \mathrm{wt} \%-3 \mathrm{wt} \%)$ was investigated for the total oxidation of toluene and ethanol by Jiratova et al. [64]. The surface acid-base properties of the catalyst were influenced under low $\mathrm{K}$ additions, while Mn oxides segregated from the original spinel-like phase at a high $\mathrm{K}$ doping, which caused significant changes in the VOCs oxidation.

The catalysts synthesized through "memory effect" of LDHs are thought to present interesting catalytic behaviors toward VOC oxidation due to their representative structures. Gennequin synthesized Co supported on calcined Mg-Al LDH catalysts using the "memory effect" and reported that the "memory ef- fect" was directly related to the toluene elimination activity [65]. The reconstruction of the $\mathrm{Mg}-\mathrm{Al}$ oxide supports can induce the formation of a high quantity of active surface Co species with a high specific area and high reducibility, which corresponds to the deep oxidation of toluene. Therefore, it can be concluded that the reconstruction of the LDHs positively influences the interaction between Co species and the support.

Meanwhile, the catalytic activities with different calcination temperatures mainly depend on the thermal treatment temperature of the catalysts. The calcination temperature influences the crystallinity of the LDH-derived catalysts, leading to the divergence of reducibility, which causes different VOC oxidation activities. Palacio et al. [55] prepared $\mathrm{ZnCuAl}$ and $\mathrm{MnCuAl}$ catalysts by a co-precipitation method and evaluated the effects of calcination at 450 and $600{ }^{\circ} \mathrm{C}$. $\mathrm{ZnCuAl}$ is an amorphous phase catalyst calcined at $450{ }^{\circ} \mathrm{C}$ and subsequently transferred to $\mathrm{Cu}$ and $\mathrm{Zn}$ oxides supported on alumina at 600 ${ }^{\circ} \mathrm{C}$ treatment. The $\mathrm{MnCuAl}$ samples calcined at $450{ }^{\circ} \mathrm{C}$ exhibit a spinel phase with lower crystallinities than those of the samples calcined at $600{ }^{\circ} \mathrm{C}$. After $450{ }^{\circ} \mathrm{C}$ treatment, $\mathrm{MnCuAl}$ catalyst presented the highest catalytic performance with $100 \%$ toluene conversion at $297{ }^{\circ} \mathrm{C}$ because it had the best textural and reductive properties. The effects of the calcination temperature on the textural properties and catalytic activity over the $\mathrm{CoMn}_{2} \mathrm{AlO}$ catalyst were further investigated. The as-prepared $\mathrm{CoMn}_{2} \mathrm{AlO}-550$ sample exhibited higher benzene catalytic activity with $T_{90}=208{ }^{\circ} \mathrm{C}$ than that of $\mathrm{CoMn}_{2} \mathrm{AlO}-450$, which was due to the formation of a solid solution with low-temperature reducibility, together with the high surface area and rich oxygen vacancies [50].

The development of the gas-phase oxidation of chlorinated VOCs with comparable activity over transition metal oxides catalysts is currently underway. Rivas prepared nanocrystalline $\mathrm{Co}_{3} \mathrm{O}_{4}$ by 5 methods, namely calcination of the precursor salt, solid-state reaction, precipitation-oxidation, precipitation, and sol-gel [56]. It can be concluded that the catalysts prepared through LDH precursors derivation exhibited the lowest temperatures with $90 \%$ 1,2-dichloroethane oxidation at $300{ }^{\circ} \mathrm{C}$. Small crystallites affording more easily accessible active sites for oxygen species adsorption and improved redox properties chiefly contribute to the high activity, which is not the case for the highly crystalline $\mathrm{Co}_{3} \mathrm{O}_{4}$ catalysts from other preparation methods. Additionally, the surface Lewis acidity plays a relevant catalytic role in promoting 1,2-dichloroethane conversion. $\mathrm{Cu} /(\mathrm{Mg}$ or $\mathrm{Ni}) / \mathrm{Al}$ mixed oxides derived from hydrotalcite-like compounds have also been evaluated for the trichloroethylene abatement. Cu-based oxides improve the catalytic activity, particularly at low temperatures, in comparison with those without $\mathrm{Cu}$. This is due to the important redox properties of $\mathrm{Cu}$ and the synergistic effect between $\mathrm{Cu}$ and $\mathrm{Ni}$. The $\mathrm{CuMgAl}$ catalysts are stable at $400{ }^{\circ} \mathrm{C}$ at least for $50 \mathrm{~h}$, which indicate that $\mathrm{Cu}$ ions are active and stable for trichloroethylene oxidation.

\subsection{VOCs catalysts based on noble metal/MMO}

Excellent low-temperature oxidation activities with long-term operating stability are essential in practical applica- 
tion for VOCs decomposition. Although various MMO through the calcination of LDHs exhibit good catalytic performance toward VOCs abatement, the low-temperature activity, initiation temperature, and durability still have gaps with supported noble metal catalysts. For example, CoAlCeO catalyst exhibits outstanding efficiency toward toluene and butanone oxidation considering both the activity and byproduct in comparison with those of commercial Pd-based materials, such as $\mathrm{Pd} / \mathrm{Al}_{2} \mathrm{O}_{3}$; however, the low-temperature activity of $T_{50 \%}$ is still much worse than that of the $\mathrm{Pd} / \mathrm{Al}_{2} \mathrm{O}_{3}$ samples [66]. This presents a good method for preparing supported noble metal catalysts through preloading noble precursors on LDH substrates (the schematic diagram is shown in Fig. 3), which is expected to induce the most desirable activity and stability with the following unique advantages: (1) uniform dispersion of the noble metal nanoparticles will be influenced by the textural properties of the support; (2) interaction of the support and noble metal will immobilize noble active species leading to thermal stability; (3) noble metals oxidation states will be affected, which will favor the low-temperature activity for VOCs oxidation.

Basile et al. [67] investigated the synthesis and thermal evolution of $\mathrm{Ru} / \mathrm{Rh}-\mathrm{MgAl} \mathrm{LDHs}$ and will favor the well-dispersed and stable noble metal particles, which results in higher activities than those of wet impregnation catalysts. The different loading approaches of noble active species on LDHs result in significantly different catalytic activities. Li et al. [58] prepared $\mathrm{Pd} / \mathrm{Co}_{3} \mathrm{AlO}$ catalysts derived from $\mathrm{Pd}$ loading CoAlLDH by impregnation (IMP), wet ion exchange (WIE), or directly at the coprecipitation stage (COP). All the $\mathrm{Pd} / \mathrm{Co}_{3} \mathrm{AlO}$ catalysts derived from LDHs exhibit high toluene oxidation activities compared with those prepared by the traditional thermal combustion method. Thus, LDH-derived $\mathrm{Pd} / \mathrm{Co}_{3} \mathrm{AlO}$ catalysts exhibit high surface areas, small mean crystallite sizes of supports, and highly dispersed PdO particles. The best activity of $\mathrm{Pd} / \mathrm{Co}_{3} \mathrm{AlO}$ (COP) with $\mathrm{T}_{90}=230{ }^{\circ} \mathrm{C}$ and few byproducts contributed to the easy reducibility and high oxygen vacancies owing to the strong synergistic effect between $\mathrm{Co}_{3} \mathrm{O}_{4}$ and $\mathrm{PdO}$, as shown in Fig. 4 [58].

The noble metal species can also play an important role in the VOCs decomposition activity. Zhao prepared different noble metal loading spinel oxides through the calcination of $\mathrm{Ag}, \mathrm{Pt}$, and Pd immobilized on CoAlLDH for toluene combustion. The $\mathrm{Pd}$-CoAlO catalyst exhibited the highest catalytic activity due to the interaction between the PdO phase and the CoAlO support, which favors the highest low-temperature reducibility, the most abundant surface $\mathrm{Co}^{3+}$, and surface adsorbed oxygen spe-

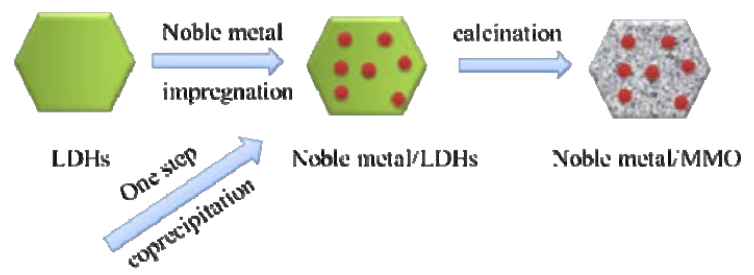

Fig. 3. Schematic diagram of the preparation of noble metal/MMO catalysts for VOCs oxidation.
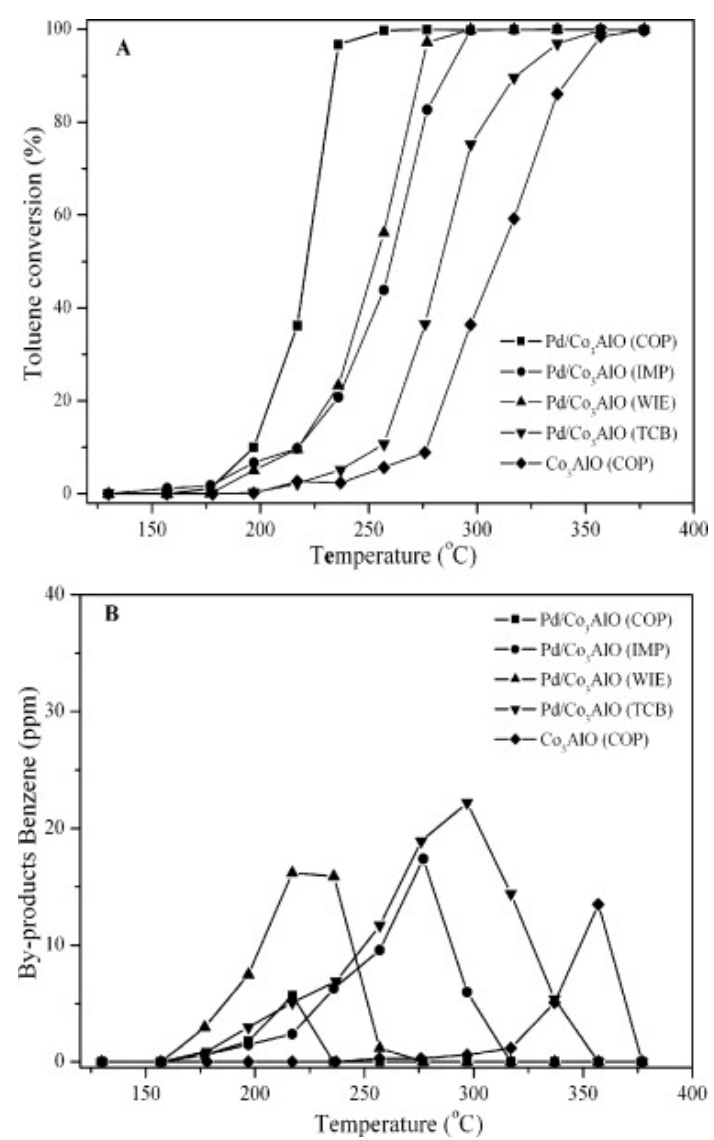

Fig. 4. Temperature-programmed curves of (A) toluene conversion and (B) the yield of the benzene byproduct over different $\mathrm{Pd} / \mathrm{Co}_{3} \mathrm{AlO}$ catalysts and $\mathrm{Co}_{3} \mathrm{AlO}$ sample [58].

cies through the cooperative effect [59]. The species of the LDH substrates that are used for noble metal loading significantly affect the performance of the VOCs oxidation. Pd-MgAlO and $\mathrm{Pd}-\mathrm{CoAlO}$ catalysts have been prepared for the comparison of their catalytic activities [59]. The activity energy of Pd-MgAlO $\left(112.5 \mathrm{~kJ} \mathrm{~mol}^{-1}\right)$ is much higher with a poor catalytic activity than that of Pd-CoAlO (49.5 kJ mol${ }^{-1}$ ) with superior toluene combustion performance, which confirms that the LDH precursors play significant roles in the VOCs oxidation, and that Co from the CoAlO support is involved in the reaction process. Furthermore, $0.5 \mathrm{wt} \% \mathrm{Pd}$-doped (Cu,Mn)-Mg-Al metal oxide catalysts were prepared by the incipient wetness impregnation of Pd ions on their corresponding LDH precursors following calcination at $500{ }^{\circ} \mathrm{C}$. The activity toward methanol oxidation decreased in the following order: $\mathrm{Pd} 0.5 / \mathrm{Cu}(0.5)-\mathrm{Mg}-\mathrm{Al}-600>$ Pd0.5/Cu-Mn-Mg-Al-600 > Pd0.5/Mg-Al-600 > Pd0.5/ Mn-Mg-Al-600 > Cu-Mn-Mg-Al > Cu(0.5)-Mg-Al > Mn-Mg-Al > $\mathrm{Mg}-\mathrm{Al}$, which confirms that the (1) calcined $\mathrm{Cu}$-containing hydrotalcite catalysts are more active than the Mn-containing hydrotalcite catalysts are; (2) incorporation of Pd significantly improves the methanol low-temperature activity due to the hydrogen dissociation and spill-over on $\mathrm{Pd}$ with the low-temperature reduction peaks splitting into two peaks [60].

\subsection{VOCs catalysts based on core-shell MMO}




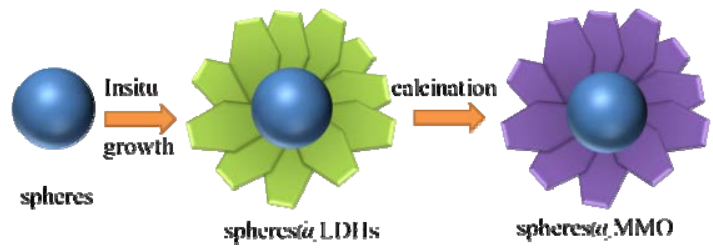

Fig. 5. Preparation process for hierarchical flower-like core-shell structured MMO catalysts.

Two-dimensional LDH-derived MMO catalysts exhibit poor control over the particle size, morphology, and crystalline orientation, which can restrict their catalytic efficiency. Recently, hierarchical flower-like core-shell structured MMO derived from LDHs have evoked remarkable interest for their excellent performance in catalytic oxidation [68] and $\mathrm{CO}_{2}$ methanation [69] due to their high surface areas, high dispersion of active phases, and their synergistic effect. Hierarchical flower-like core-shell structured mixed metal oxides can be reproducibly prepared by in situ growth of a two-dimensional LDH precursor on amorphous $\mathrm{Al}_{2} \mathrm{O}_{3}$ [70], $\mathrm{Fe}_{2} \mathrm{O}_{3}$ [71,72], $\mathrm{SiO}_{2}$ [73], and $\mathrm{TiO}_{2}$ [74] spheres or ZIF-67 [75], followed by calcination, and the schematic of the preparation process is shown in Fig. 5. Li's group prepared hierarchical flower-like core-shell structured CoZ-
nAlO and CoCuAlO supported on alumina via an in situ growing LDH precursor route, which exhibited high dispersion of Co species due to well-developed three-dimensional flower-like mixed metal oxides platelets [70,76].

Wang reported a two-step method to construct a 3D hierarchical $\mathrm{NiCo}_{2} \mathrm{O}_{4} / \mathrm{NiO}$ nanocage through a partial in situ transformation of ZIF-67 into Co-NiLDH yolk-shelled structures following calcination [75]. The CoNi-6h-350 sample showed much higher toluene oxidation activity with lower $T_{90}$ of $229^{\circ} \mathrm{C}$ due to the abundant surface high valence Co ions owing to the novel hierarchical nanostructures.

Zhao et al. [77] successfully prepared hierarchical core-shell $\mathrm{Al}_{2} \mathrm{O}_{3} @ \mathrm{Pd}-\mathrm{CoAlO}$ (Pd-CoAlO-Al) microspheres and Pd-CoAlO catalysts lacking core-shell structures (Pd-CoAlO-S), and examined their toluene abatement performance. Fig. 6 indicates that they all show hierarchical microsphere structures. The results in Fig. 6 and Table 2 reveal that the core-shell Pd-CoAlO-Al exhibits significantly better catalytic efficiency with the lower $T_{90}$ temperature of $207^{\circ} \mathrm{C}$ and higher TOF $\mathrm{F}_{\mathrm{Co}}$ and

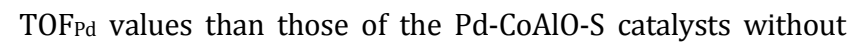
core-shell structures with $T_{90}$ of $229^{\circ} \mathrm{C}$. The discrepancy on the catalytic activity is probably due to the homogeneous distribution of well-developed 3D flower-like Pd-CoAlO nanosheets on $\mathrm{Al}_{2} \mathrm{O}_{3}$ supports.

A)
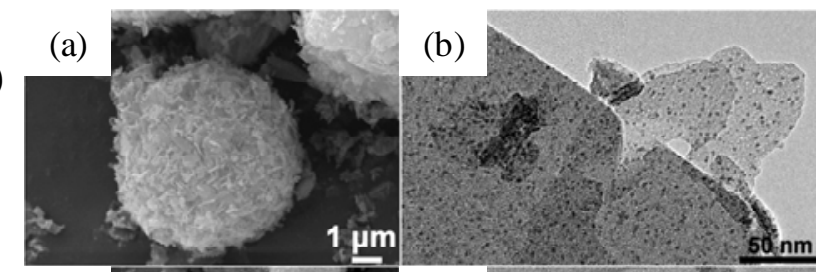

(c)
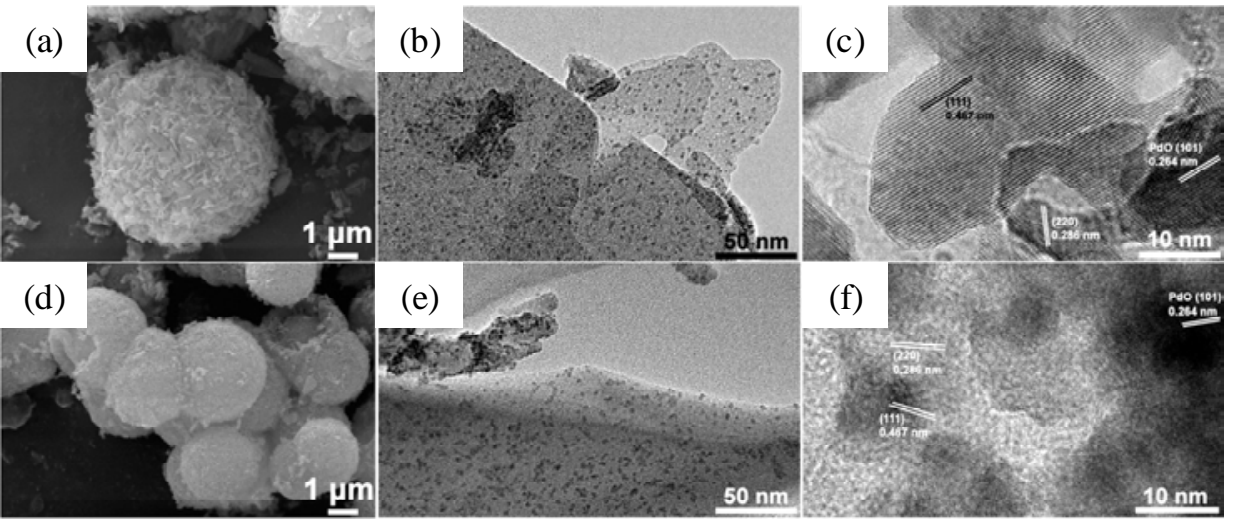

\section{(f)}

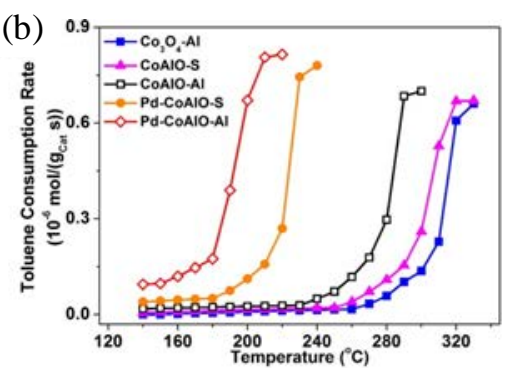

B)

(a)

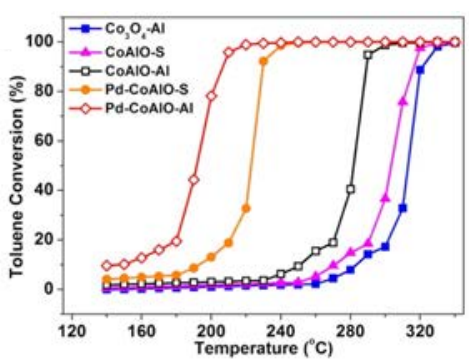

(c)

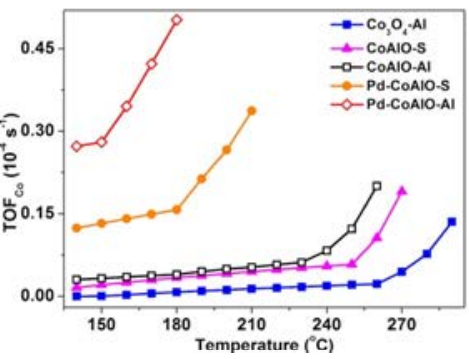

(d)

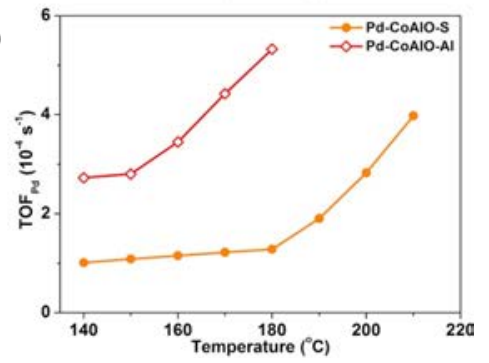

Fig. 6. (A) SEM and TEM results of Pd-CoAlO-S (a-c) and Pd-CoAlO-Al (d-f); (B) toluene conversion (a), toluene consumption rate (b), TOF $\mathrm{F}_{\mathrm{Co}}(\mathrm{c})$, and $\mathrm{TOF}_{\mathrm{Pd}}(\mathrm{d})$ as a function of temperature. Reaction conditions: $2000 \mathrm{ppm}$ toluene, and GHSV $=60000 \mathrm{~mL} \cdot \mathrm{g}^{-1} \cdot \mathrm{h}^{-1}$ ) [77]. 
Table 2

Summary of the publications in recent years on transition metal-based structured catalysts for the catalytic oxidation of VOCs.

\begin{tabular}{|c|c|c|c|c|c|c|}
\hline $\begin{array}{l}\text { Catalyst with calcination } \\
\text { temperature }\end{array}$ & Method & VOCs & $\begin{array}{c}\text { Space velocity } \\
\left(\mathrm{mL} \cdot \mathrm{g}^{-1} \cdot \mathrm{h}^{-1}\right)\end{array}$ & $\begin{array}{c}\text { Temperature } \\
\left({ }^{\circ} \mathrm{C}\right) \\
\end{array}$ & $\begin{array}{c}\text { Conversion } \\
(\%)\end{array}$ & Refs. \\
\hline Pd-CoAlO-Al-600 & In situ growth on $\mathrm{Al}_{2} \mathrm{O}_{3}$ sphere & 2000 ppm toluene & 60000 & 207 & 90 & [77] \\
\hline $\mathrm{NiCO}_{2} \mathrm{O}_{4} / \mathrm{NiO}-350$ & In situ transformation ZIF@LDH & $200 \mathrm{ppm}$ toluene & 60000 & 229 & 90 & {$[75]$} \\
\hline NiCuMn-Al film-500 & Hydrothermal on Al substrate & $1.0 \mathrm{~g} \cdot \mathrm{m}^{-3}$ ethanol & 20000 & 228 & 90 & [78] \\
\hline NiCoMn-Al film-500 & Hydrothermal on Al substrate & $1.0 \mathrm{~g} \cdot \mathrm{m}^{-3}$ ethanol & 20000 & 262 & 90 & {$[78]$} \\
\hline $\mathrm{CoMn}_{2} \mathrm{AlO}$-film-400 & Hydrothermal on Al substrate & 100 ppm benzene & 300000 & 238 & 90 & {$[79]$} \\
\hline $\mathrm{Co}_{3} \mathrm{AlO}$-film-400 & Hydrothermal on $\mathrm{Al}$ substrate & $100 \mathrm{ppm}$ benzene & 300000 & 302 & 90 & [79] \\
\hline $\mathrm{Mn}_{3} \mathrm{AlO}$-film-400 & Hydrothermal on $\mathrm{Al}$ substrate & 100 ppm benzene & 300000 & 265 & 90 & [79] \\
\hline Co1.5Mn1.50 $4-400$ & Urea hydrothermal on $\mathrm{Ni}$ foam substrate & $1000 \mathrm{ppm}$ toluene & 30000 & 270 & 100 & [80] \\
\hline $\mathrm{Co}_{2} \mathrm{AlO}_{4} / \mathrm{Ni}$ foam-350 & Hydrothermal on $\mathrm{Ni}$ foam substrate & $1000 \mathrm{ppm}$ toluene & 300000 & 272 & 99 & [81] \\
\hline
\end{tabular}

\subsection{VOC catalysts based on integral MMO}

Integral catalysts have generated widespread interest for VOCs degradation in practical environments with high catalytic activity and low-pressure drops. Integral LDH-based film catalysts can be in situ, grown on a monolithic metal substrate, which exhibit relatively high adhesion to the substrate and adequate exposure of the active phase [82-84]. Duan's group developed growing orientation LDH films on Al substrates or other substrates [84-86]. The LDH films growing on monolithic metal substrates are uniform and compact with excellent adhesion to the substrate [87]. Besides, the rational design and controllable preparation of monolithic mixed metal oxide film catalysts from LDH materials will lead to unexpected VOC activity $[83,88]$; some typical references are listed in Table 2.

Integral MMO containing various combinations of $\mathrm{Cu}, \mathrm{Co}, \mathrm{Ni}$, $\mathrm{Mn}$, and $\mathrm{Al}$ supported on oxidized $\mathrm{Al}$ foil $\mathrm{Al}_{2} \mathrm{O}_{3} / \mathrm{Al}$ have been successfully fabricated and characterized, including their chemical composition, porous structure, reducibility, and oxidation activity [89]. Among the supported catalysts, the $\mathrm{Ni}-\mathrm{Cu}-(\mathrm{Mn})-\mathrm{Al}$ mixed oxide is the most active for ethanol oxidation. Synthetic conditions including the $\mathrm{pH}$ during the hydrothermal deposition of the LDH precursors will induce distinct catalytic activities [78]. Li et al. [79] synthesized a series of CoMnAlO film catalysts based on in situ supported LDHs through an ammonia hydrothermal growing process on Al substrate following calcinations, and evaluated the effect of the $\mathrm{Co} / \mathrm{Mn}$ molar ratio for benzene oxidation. The orientation of the film catalyst consisting of thin curved hexagonal platelets, shown in Fig. 7, is perpendicular to the substrate, which is prone to having a high number of active sites located on the edges of the crystallites. The results indicate that the $\mathrm{CoMn}_{2} \mathrm{AlO}$ film sample exhibits the lowest $\mathrm{T}_{90}$ of $238^{\circ} \mathrm{C}$. Furthermore, the

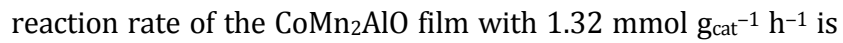
about five times higher than that of the $\mathrm{CoMn}_{2} \mathrm{AlO}$ powder catalyst due to the high number of exposed active sites [79].

Integral structured Co-Mn composite oxides grown on the 3D ordered network of Ni foam substrates with varied Co:Mn molar ratios were fabricated by the urea hydrothermal method and tested for toluene decomposition. The molar ratio has a significant effect on the toluene oxidation. Among them, $\mathrm{Co}_{1.5} \mathrm{Mn}_{1.5} \mathrm{O}_{4}$ exhibits the best activity with a complete oxidation temperature of $270{ }^{\circ} \mathrm{C}$ due to the formation of a solid solution with $\mathrm{Co}$ and $\mathrm{Mn}$ species in the 1:1 ratio, resulting in outstanding oxidation performance [80]. Mo et al. [81] fabricated monolith- ic catalysts by decorating leaf-like Co-ZIF-L derivatives on $\mathrm{Co}_{2} \mathrm{AlO}_{4}$ coral-like microspheres from CoAlLDHs coated on 3D porous Ni foam substrates. The distinct catalyst exhibits outstanding activity $\left(T_{99}=272^{\circ} \mathrm{C}\right)$, cycling stability, and long-term stability toward toluene abatement, which was ascribed to its unique structure with a high specific surface area, relatively low-temperature reducibility, rich surface oxygen vacancy, and high valence $\mathrm{Co}^{3+}$ species.

\section{VOCs catalysts with the effect of water vapor}

Besides the pursuit of high activity and long-term stability of the prepared catalysts, humidity resistance is a quite important target for practical VOCs oxidation. Li et al. [49] reported that the $\mathrm{Co}_{2} \mathrm{NiAlO}$ catalyst exhibits essentially the same benzene conversion activity over three separate temperature-programming system tests, which indicates the good reproducibility and reversibility of the catalyst, as shown in Fig. 8. The Co2NiAlO catalyst can also endure long time-on-stream catalytic process lasting for $30 \mathrm{~h}$ under three temperatures of 200,300 , and $400{ }^{\circ} \mathrm{C}$ in sequence, indicating the long-term stability of the catalysts even under relatively high-temperature conditions. The 3.5\% water vapor can cause a significant drop of nearly $10 \%$ in the benzene conversion at low temperatures, although there is a negligible negative effect on the catalytic activity at high temperatures, as shown in Fig. 8. Water vapor is expected to competitively cover partially active sites to restrain the adsorption of VOCs and oxygen at a low temperature of 240 ${ }^{\circ} \mathrm{C}$, leading to undistinguished activities, while the reduction of
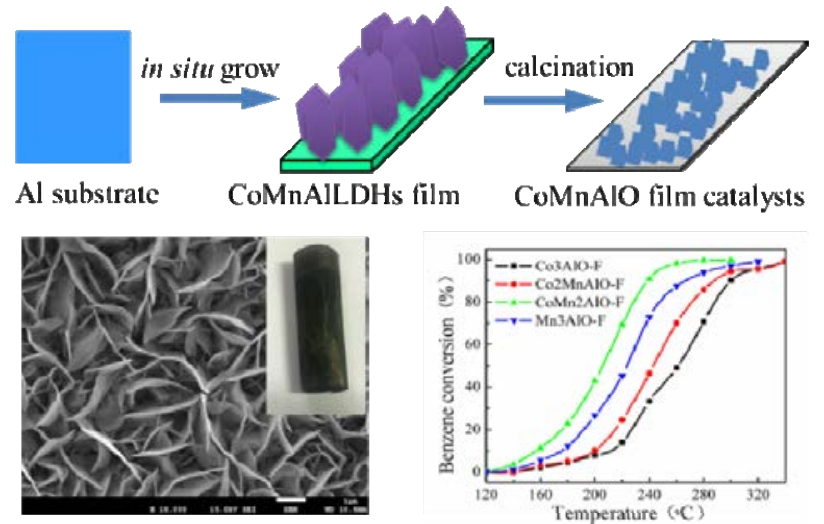

Fig. 7. Schematic of the integrated film catalysts prepared by the in situ growth method. SEM image and photograph for CoMnAlO-F and their benzene oxidation curves [79]. 

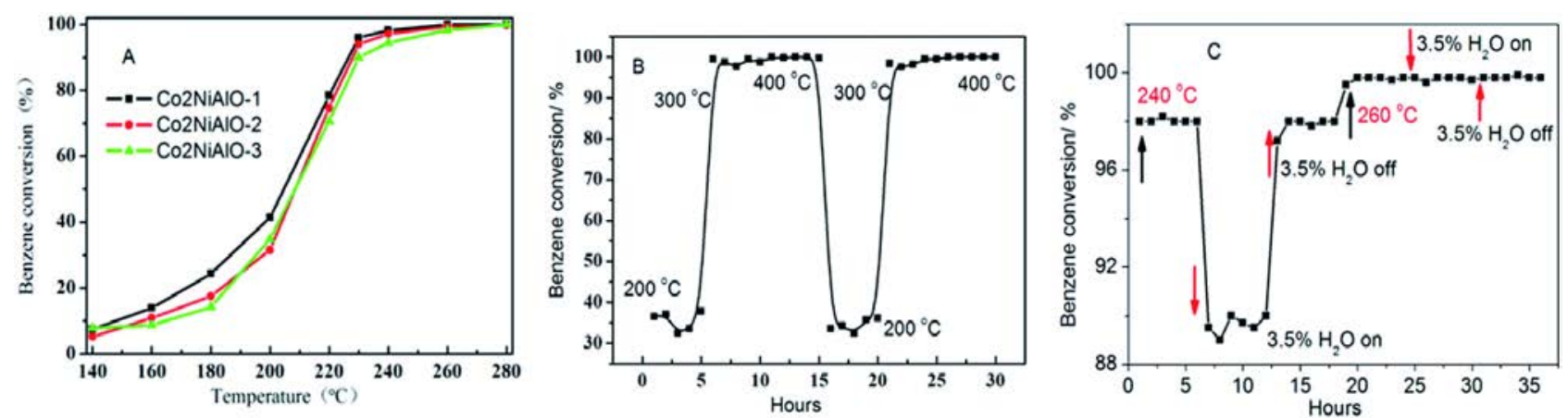

Fig. 8. Reproducibility (A) and benzene conversion (B) as a function of the reaction temperature and time over the CoxNiAlO catalysts; (C) the effect of $3.5 \%$ water vapor over the $\mathrm{Co}_{2} \mathrm{NiAlO}$ catalyst. (100 ppm, $60000 \mathrm{~mL} \mathrm{~g}_{\mathrm{cat}^{-1}} \mathrm{~h}^{-1}$ ) [49].

the water vapor adsorbed on the surface of active species results in excellent catalytic activity at a high temperature of 260 ${ }^{\circ} \mathrm{C}$ [49]. The CuCoAlO catalyst can also tolerate the effect of water vapor to a certain extent at $320^{\circ} \mathrm{C}$ [48]. However, the CoMnAlO structured catalyst growing on an $\mathrm{Al}$ plate substrate exhibits poor water vapor tolerance with $30 \%$ decrease in the benzene activity at $320^{\circ} \mathrm{C}$, which may be attributed to the divergence due to the exposure extent of active sites over film and powder catalysts [79]. Fortunately, most of the catalysts will gradually and partially recover their activity after removing the water vapor, which indicates that water vapor causes no permanent damage to the active sites through the desorption of the competitively adsorbed water on the active sites [48-50,79].

\section{Reaction mechanism of the VOC catalysts}

It is quite important to design heterogeneous LDH-based catalysts with high activities toward VOC oxidation based on the understanding of the surface oxidation mechanism. There are commonly three kinetic models: Langmuir-Hinshelwood (L-H), Eley-Rideal (E-R), and Mars-van Krevelen (MvK), which are suitable for explaining the mechanism of the VOC catalytic oxidation. The L-H model predicts that the adsorbed oxygen species and adsorbed VOC molecules react with each other on active sites with the controlling step of the surface reaction. The E-R model assumes that the adsorbed molecules on the active sites of the catalysts react with molecules from the gas phase, which is regarded as the rate-controlling step. The MvK mechanism is mainly based on the redox reaction (Fig. 9): firstly, VOC species are oxidized by surface oxygen species, and subsequently, oxygen vacancies are produced and the metal sites are reduced. Secondly, the oxygen in the air will re-oxidize the reduced metal centers, thereby eliminating the oxygen vacancies $[21,90]$. The catalytic composition, physicochemical properties, and VOC components will influence the surface oxidation mechanism.

The MvK mechanism model is usually used to describe the incineration of VOC over metal oxide catalysts [50,54,91]. The reaction mechanism of the benzene oxidation over CoMnAlO at different calcination temperatures was studied by Mo-based on XPS results, which is related to the MvK model [50]. Mo observed the good synergistic effect between Co and Mn through the following redox electronic transfer: $\mathrm{Co}^{3+}-\mathrm{Mn}^{3+} \leftrightarrow \mathrm{Co}^{2+}-\mathrm{Mn}^{4+}$, which is critical to the catalytic reaction after the formation of Co and Mn mixed oxides. The CoMn $2 \mathrm{AlO}-350$ sample under low-temperature treatment with a relatively high $\mathrm{Mn}^{4+} / \mathrm{Mn}^{3+}$ molar ratio will contain more adsorbed oxygen species, which are responsible for the high catalytic activity. $\mathrm{CoMn}_{2} \mathrm{AlO}-550$, under high-temperature treatment with a relatively high $\mathrm{Co}^{3+} / \mathrm{Co}^{2+}$ molar ratio, will result in more lattice oxygen species, leading to the highest benzene oxidation activity.

To investigate the promotor of the $\mathrm{PdO}$ phase in the toluene reaction process, $\mathrm{Pd}-\mathrm{CoAlO}-\mathrm{N}_{2}$ and $\mathrm{Pd}-\mathrm{CoAlO}$-Air were prepared under different calcination atmospheres. From the results, it can be concluded that the PdO phase plays a key role and the PdO phase and CoAlO support participate cooperatively during the toluene abatement process [59]. Furthermore, in situ DRIFTS experiments were employed to evaluate the intermediate species and reaction mechanism over CoAlO and $\mathrm{Ag} / \mathrm{Pt} / \mathrm{Pd}-\mathrm{CoAlO}$. Toluene combustion mainly experiences steps involving benzylic, aldehydic, and benzoate species in sequence over CoAlO catalysts. However, aldehydic species are absent over $\mathrm{Ag} / \mathrm{Pt} / \mathrm{Pd}$-CoAlO catalysts, which indicates that benzoate species are the primary intermediate species in the toluene oxidation [59].

\section{Summary and perspectives}

Increasing VOC emissions contribute significantly to the formation of tropospheric ozone and secondary organic aerosols. Catalytic oxidation over noble metals or transitional metal oxide catalysts is one of the best strategies for VOCs abatement. This review provides insights into the preparation method and structure-performance of LDH-derived catalysts for VOCs decomposition based on MMO, noble metal loading MMO,

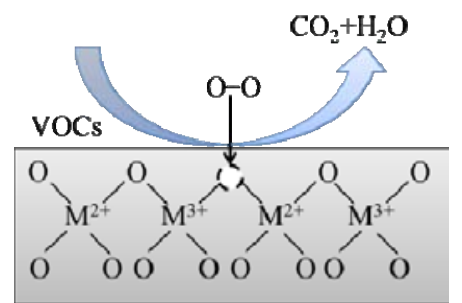

Fig. 9. Schematic diagram of the Mars-van Krevelen (MvK) mechanism over the LDH-derived MMO catalysts. 
core-shell MMO, and integrated MMO on metal support catalysts. Many kinds of transition metals cations can be introduced into the LDH layer, which can be topologically transformed into MMO by controlled thermal decomposition. Due to the LDHs, related MMO catalysts inherit unique structures, compositional flexibility, and versatile physicochemical properties, which make them promising catalysts for total VOCs oxidation. The application of LDHs as supports for noble metal loading is also an important strategy for supporting noble metal catalysts for VOCs elimination, which leads to high dispersion of noble active sites and strong metal-support interaction. Besides, the core-shell structure or integrated MMO catalysts result in new avenues for heterogeneous catalysis with hierarchical structures, which is convenient for high exposure of active sites, and the interaction of VOCs molecules with active sites. Visible or infrared light-driven VOCs oxidation also provides an exciting pathway for the potential application because sunlight is an inexhaustible energy source and semiconductor oxides with adjustable band gap from LDH-based catalysts can produce photogenerated electrons and holes [92-94]. Recently, benefiting from the universal regulatory property of LDH layers, LDH-derived MMO have also been extensively studied for application in the catalytic conversion of high value-added products [95-97], including ethanol conversion to diethyl carbonate, acetone conversion to methyl isobutyl ketone, and dimethyl carbonate synthesis. However, there are still significant challenges associated with the design and application of LDH-derived MMO catalysts. Firstly, the formation and conversion of hetero-structured interfaces during the topotactic transformation of LDH precursors with varied host compositions to their corresponding MMO materials, has not been well understood and remains elusive. Secondly, the surface VOC oxidation mechanisms over the unique MMO structures derived from the LDH structures deserve intensive study. Such a study would be of crucial for designing heterogeneous catalysts. Thirdly, catalyst deactivation over coking, poisoning, sintering, and regeneration is still a long way from being elucidated over LDH-derived catalysts. We firmly believe that the con- trollable design and synthesis of LDH-based materials should contribute significantly to the development of new practical catalysts for the abatement of VOCs.

\section{References}

[1] C. S. Liang, F. K. Duan, K. B. He, Y. L. Ma, Environ. Int., 2016, 86, 150-170.

[2] J. J. Zhang, J. M. Samet, J. Thorac. Dis., 2015, 7, 3-13.

[3] C. Liu, Y. P. Zhang, C. J. Weschler, Sci. Total Environ., 2014, 497, 401-411.

[4] R. J. Huang, Y. Zhang, C. Bozzetti, K. F. Ho, J. J. Cao, Y. Han, K. R. Daellenbach, J. G. Slowik, S. M. Platt, F. Canonaco, P. Zotter, R. Wolf, S. M. Pieber, E. A. Bruns, M. Crippa, G. Ciarelli, A. Piazzalunga, M. Schwikowski, G. Abbaszade, J. Schnelle-Kreis, R. Zimmermann, Z. An, S. Szidat, U. Baltensperger, I. El Haddad, A. S. H. Prevot, Nature, 2014, 514, 218-222.

[5] M. Y. Gong, Y. P. Zhang, C. J. Weschler, Environ.Sci. Technol., 2014, 48, 7428-7435.

[6] L. Ran, C. S. Zhao, W. Y. Xu, X. Q. Lu, M. Han, W. L. Lin, P. Yan, X. B. $\mathrm{Xu}$, Z. Z. Deng, N. Ma, P. F. Liu, J. Yu, W. D. Liang, L. L. Chen, Atmos. Chem. Phys., 2011, 11, 4657-4667.

[7] A. Mellouki, G. L. Bras, H. Sidebottom, Chem. Rev., 2003, 103, 5077-5096.

[8] X. Zhang, J. Ye, Y. Jing, T. Cai, X. Bei, L. Zhe, K. Zhao, Y. Ling, D. He, Appl. Catal. A, 2018, 566, 104-112.

[9] Y. Wang, H. Arandiyan, Y. Liu, Y. Liang, Y. Peng, S. Bartlett, H. Dai, S. Rostamnia, J. Li, ChemCatChem, 2018, 10, 3429-3434.

[10] H. Xu, N. Yan, Z. Qu, W. Liu, J. Mei, W. Huang, S. Zhao, Environ. Sci. Technol., 2017, 51, 8879-8892.

[11] F. I. KhanA. K. Ghoshal, J. Loss Prevent. Proc. Ind., 2000, 13, 527-545.

[12] S. Ojala, S. Pitkaaho, T. Laitinen, N. N. Koivikko, R. Brahmi, J. Gaalova, L. Matejova, A. Kucherov, S. Paivarinta, C. Hirschmann, T. Nevanpera, M. Riihimaki, M. Pirila, R. L. Keiski, Top. Catal., 2011, 54, 1224-1256.

[13] J. Li, H. Liu, Y. Deng, G. Liu, Y. Chen, J. Yang, Nanotechnol. Rev., 2016, 5, 147-181.

[14] W. M. Li, H. D. Liu, X. Ma, S. P. Mo, S. D. Li, Y. F. Chen, J. Porous Mater., 2018, 25, 107-117.

[15] Y. Z. Deng, W. X. Tang, W. H. Li, Y. F. Chen, Catal. Today, 2018, 308,

\section{Graphical Abstract}

\section{Chin. J. Catal., 2020, 41: 550-560 doi: S1872-2067(19)63446-7}

\section{Recent advance on Vocs oxidation over layered double hydroxides derived mixed metal oxides}

Shuangde Li, Dongdong Wang, Xiaofeng Wu, Yunfa Chen* Institute of Process Engineering, Chinese Academy of Sciences; University of Chinese Academy of Sciences;

Institute of Urban Environment, Chinese Academy of Sciences

This review summarizes the developments in the LDH-derived VOCs heterogeneous catalytic oxidation over the last 10 years based on the following 4 aspects: MMO, noble metal/MMO, core-shell structured MMO, and integral MMO film catalysts.

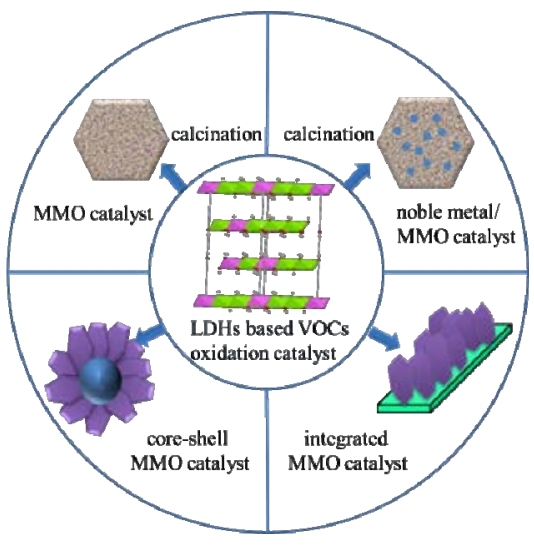


$58-63$.

[16] Z. Cuo, Y. Deng, W. Li, S. Peng, F. Zhao, H. Liu, Y. Chen, Appl. Surf. Sci., 2018, 456, 594-601.

[17] W. X. Tang, Y. Z. Deng, Y. F. Chen, Catal. Commun., 2017, 89, 86-90.

[18] W. X. Tang, G. Liu, D. Y. Li, H. D. Liu, X. F. Wu, N. Han, Y. F. Chen, Sci. China Chem., 2015, 58, 1359-1366.

[19] L. F. Liotta, Appl. Catal. B, 2010, 100, 403-412.

[20] M. S. Kamal, S. A. Razzak, M. M. Hossain, Atmos. Environ., 2016, $140,117-134$.

[21] C. He, J. Cheng, X. Zhang, M. Douthwaite, S. Pattisson, Z. Hao, Chem. Rev., 2019, 119, 4471-4568.

[22] Y. N. Liu, J. Y. Zhao, J.T. Feng, Y. F. He, Y. Y. Du, D. Li, J. Catal., 2018, 359, 251-260.

[23] Y. Zhao, X. Jia, G. I. N. Waterhouse, L. Z. Wu, C. H. Tung, D. O'Hare, T. Zhang, Adv. Energy Mater., 2016, 6, 1501974.

[24] G. Cui, X. Meng, X. Zhang, W. Wang, S. Xu, Y. Ye, K. Tang, W. Wang, J. Zhu, M. Wei, D. G. Evans, X. Duan, Appl. Catal. B, 2019, 248, 394-404.

[25] S. Zheng, J. Lu, D. Yan, Y. Qin, H. Li, D. G. Evans, X. Duan, Sci. Rep., 2015, 5, 12170-12177.

[26] Z. Li, H. Duan, M. Shao, J. Li, D. O'Hare, M. Wei, Z. L. Wang, Chem, 2018, 4, 2168-2179.

[27] P. J. Sideris, U. G. Nielsen, Z. Gan, C. P. Grey, Science, 2008, 321, 113-117.

[28] R. Tian, R. Liang, M. Wei, D. G. Evans, X. Duan, Struct. Bond., 2016, $172,65-84$.

[29] S. He, Z. An, M. Wei, D. G. Evans, X. Duan, Chem. Commun., 2013, 49, 5912-5920.

[30] Q. Wang, D. O'Hare, Chem. Rev., 2012, 112, 4124-4155.

[31] M. Shao, F. Ning, M. Wei, D. G. Evans, X. Duan, Adv. Funct. Mater., 2014, 24, 580-586.

[32] Y. Zhao, Q. Wang, T. Bian, H. Yu, H. Fan, C. Zhou, L. Z. Wu, C. H. Tung, D. O'Hare, T. Zhang, Nanoscale, 2015, 7, 7168-7173.

[33] Q. Yan, S. Chen, C. Zhang, D. O'Hare, Q. Wang, J. Colloid Interf. Sci., 2018, 526, 63-74.

[34] R. Yang, Y. Cui, Q. Yan, C. Zhang, L. Qiu, D. O'Hare, Q. Wang, Chem. Eng. J., 2017, 326, 656-666.

[35] Q. Yan, R. Yang, Y. Zhang, A. Umar, Z. Huang, Q. Wang, Environ. Prog. Sustain. Energy, 2016, 35, 1061-1069.

[36] J. Wang, L. Huang, Q. Zheng, Y. Qiao, Q. Wang, J. Ind. Eng. Chem., 2016, 36, 255-262.

[37] J. Wang, L. Huang, R. Yang, Z. Zhang, J. Wu, Y. Gao, Q. Wang, D. O'Hare, Z. Zhong, Energy Environ Sci, 2014, 7, 3478-3518.

[38] Z. P. Xu, J. Zhang, M. O. Adebajo, H. Zhang, C. Zhou, Appl. Clay. Sci,, 2011, 53, 139-150.

[39] G. Fan, F. Li, D. G. Evans, X. Duan, Chem. Soc. Rev., 2014, 43, 7040-7066.

[40] T. Baskaran, J. Christopher, A. Sakthivel, RSC Adv., 2015, 5, 98853-98875.

[41] J. Feng, Y. He, Y. Liu, Y. Du, D. Li, Chem. Soc. Rev., 2015, 44, 5291-5319.

[42] M. H. Castaño, R. Molina, S. Moreno, Appl. Catal. A, 2015, 492, 48-59.

[43] Y. Xu, Z. Wang, L. Tan, Y. Zhao, H. Duan, Y. F. Song, Ind. Eng. Chem. Res., 2018, 57, 10411-10420.

[44] Y. Xu, Z. Wang, L. Tan, H. Yan, Y. Zhao, H. Duan, Y. F. Song, Ind. Eng. Chem. Res., 2018, 57, 5259-5267.

[45] Y. Zhao, X. Jia, G. Chen, L. Shang, G. I. N. Waterhouse, L. Z. Wu, C. H. Tung, D. O'Hare, T. Zhang, J. Am. Chem. Soc., 2016, 138, 6517-6524.

[46] S. Mo, S. Li, J. Li, Y. Deng, S. Peng, J. Chen, Y. Chen, Nanoscale, 2016,
8, 15763-15773

[47] S. Mo, S. Li, J. Li, S. Peng, J. Chen, Y. Chen, Catal. Commun., 2016, 87, 102-105.

[48] S. Li, H. Wang, W. Li, X. Wu, W. Tang, Y. Chen, Appl. Catal. B, 2015, 166-167, 260-269.

[49] S. Li, S. Mo, J. Li, H. Liu, Y. Chen, RSC Adv., 2016, 6, S6874-S6884.

[50] S. Mo, S. Li, W. Li, J. Li, J. Chen, Y. Chen, J. Mater. Chem. A, 2016, 4, 8113-8122.

[51] Q. Zhao, Y. Ge, K. Fu, N. Ji, C. Song, Q. Liu, Chemosphere, 2018, 204, 257-266.

[52] K. Jiratova, F. Kovanda, J. Ludvikova, J. Balabanova, J. Klempa, Catal. Today, 2016, 277, 61-67.

[53] D. Li, Y. Fan, Y. Ding, X. Wei, Y. Xiao, Catal. Commun., 2017, 88, 60-63.

[54] E. Genty, J. Brunet, C. Poupin, S. Casale, S. Capelle, P. Massiani, S. Siffert, R. Cousin, Catalysts, 2015, 5, 851-867.

[55] L. A. Palacio, J. Velasquez, A. Echavarria, A. Faro, F. R. Ribeiro, M. F. Ribeiro, J Hazard. Mater., 2010, 177, 407-413.

[56] B. de Rivas, R. López-Fonseca, C. Jiménez-González, J. I. Gutiérrez-Ortiz, J. Catal., 2011, 281, 88-97.

[57] N. Blanch-Raga, A. E. Palomares, J. Martínez-Triguero, G. Fetter, P. Bosch, Ind. Eng. Chem. Res., 2013, 52, 15772-15779.

[58] P. Li, C. He, J. Cheng, C. Y. Ma, B. J. Dou, Z. P. Hao, Appl. Catal. B, 2011, 101, 570-579.

[59] S. Zhao, K. Li, S. Jiang, J. Li, Appl. Catal. B, 2016, 181, 236-248.

[60] L. Chmielarz, M. Jabłońska, A. Węgrzyn, K. Góra-Marek, Z. Piwowarska, S. Witkowski, A. Wach, P. Kuśtrowski, D. Majda, E. Bidzińska, Apply. Clay. Sci., 2015, 114, 273-282.

[61] E. Genty, R. Cousin, S. Capelle, C. Gennequin, S. Siffert, Eur. J. Inorg. Chem., 2012, 2012, 2802-2811.

[62] D. A. Aguilera, A. Perez, R. Molina, S. Moreno, Appl. Catal. B, 2011, 104, 144-150.

[63] M. H. Castaño, R. Molina, S. Moreno, Catalysts, 2015, 5, 905-925.

[64] K. Jiratova, J. Mikulova, J. Klempa, T. Grygar, Z. Bastl, F. Kovanda, Appl. Catal. A, 2009, 361, 106-116.

[65] C. Gennequin, T. Barakat, H. L. Tidahy, R. Cousin, J. F. Lamonier, A. Aboukaïs, S. Siffert, Catal. Today, 2010, 157, 191-197.

[66] J. Brunet, E. Genty, C. Barroo, F. Cazier, C. Poupin, S. Siffert, D. Thomas, G. De Weireld, T. Visart de Bocarmé, R. Cousin, Catalysts, 2018, 8, 64/1-64/20.

[67] F. Basile, L. Basini, G. Fornasari, M. Gazzano, F. Trifirò, A. Vaccari, Chem. Commun., 1996, 2435-2436.

[68] Y. Y. Du, Q. Jin, J. T. Feng, N. Zhang, Y. F. He, D. Q. Li, Catal. Sci. Technol, 2015, 5, 3216-3225.

[69] S. He, C. Li, H. Chen, D. Su, B. Zhang, X. Cao, B. Wang, M. Wei, D. G. Evans, X. Duan, Chem. Mater., 2013, 25, 1040-1046.

[70] R. Xie, G. Fan, L. Yang, F. Li, Chem. Eng. J., 2016, 288, 169-178.

[71] M. Shao, F. Ning, J. Zhao, M. Wei, D. G. Evans, X. Duan, J. Am. Chem. Soc., 2012, 134, 1071-1077.

[72] L. Li, R. Li, S. Gai, F. He, P. Yang, J. Mater. Chem. A, 2014, 2, 8758-8765.

[73] M. Shao, F. Ning, Y. Zhao, J. Zhao, M. Wei, D. G. Evans, X. Duan, Chem. Mater, 2012, 24, 1192-1197.

[74] Y. Dou, S. Zhang, T. Pan, S. Xu, A. Zhou, M. Pu, H. Yan, J. Han, M. Wei, D. G. Evans, X. Duan, Adv. Funct. Mater., 2015, 25, 2243-2249.

[75] D. Wang, S. Li, Y. Du, X. Wu, Y. Chen, Catalysts, 2019, 9, 352.

[76] R. Xie, G. Fan, L. Yang, F. Li, Catal. Sci. Technol., 2015, 5, 540-548.

[77] S. Zhao, F. Hu, J. Li, ACS Catal., 2016, 6, 3433-3441.

[78] F. Kovanda, K. Jiratova, Appl. Clay. Sci., 2011, 53, 305-316.

[79] S. Li, S. Mo, D. Wang, X. Wu, Y. Chen, Catal. Today, 2019, 332, 132-138. 
[80] X. Jiang, W. Xu, S. Lai, X. Chen, RSC Adv., 2019, 9, 6533-6541.

[81] S. Mo, Q. Zhang, Q. Ren, J. Xiong, M. Zhang, Z. Feng, D. Yan, M. Fu, J. Wu, L. Chen, D. Ye, J. Hazard. Mater., 2019, 364, 571-580.

[82] C. Zhao, J. Wu, L. Yang, G. Fan, F. Li, Ind. Eng. Chem. Res., 2017, 56, 4237-4244.

[83] F. Kovanda, K. Jiratova, J. Ludvikova, H. Raabova, Appl. Catal. A, 2013, 464, 181-190.

[84] X. Guo, F. Zhang, D. G. Evans, X. Duan, Chem. Commun., 2010, 46, 5197-5210.

[85] X. Guo, F. Zhang, S. Xu, D. G. Evans, X. Duan, Chem Commun, 2009, 6836-6838.

[86] Y. Zhao, M. Wei, J. Lu, Z. L. Wang, X. Duan, ACS Nano, 2009, 3, 4009-4016.

[87] X. Guo, S. Xu, L. Zhao, W. Lu, F. Zhang, D. G. Evans, X. Duan, Langmuir, 2009, 25, 9894-9897.

[88] F. Kovanda, K. Jirátová, Catal. Today, 2011, 176, 110-115.

[89] J. Ludvíková, K. Jirátová, F. Kovanda, Chem. Pap., 2012, 66,
589-597.

[90] Z. Zhang, Z. Jiang, W. Shangguan, Catal. Today, 2016, 264, 270-278.

[91] H. C. Genuino, S. Dharmarathna, E. C. Njagi, M. C. Mei, S. L. Suib, J. Phys. Chem. C, 2012, 116, 12066-12078.

[92] J. J. Li, S. C. Cai, E. Q. Yu, B. Weng, X. Chen, J. Chen, H. P. Jia, Y. J. Xu, Appl. Catal. B, 2018, 233, 260-271.

[93] Y. Zhao, W. Gao, S. Li, G. R. Williams, A. H. Mahadi, D. Ma, Joule, 2019, 3, 920-937.

[94] S. Fu, Y. Zheng, X. Zhou, Z. Ni, S. Xia, J. Hazard. Mater., 2019, 363, 41-54.

[95] J. Zhang, T. Yan, Y. Yang, J. Sun, Y. Lin, M. Wei, Chin. J. Catal., 2019, $40,515-522$.

[96] Y. Liao, F. Li, X. Dai, N. Zhao, F. Xiao, Chin. J. Catal., 2017, 38, 1860-1869.

[97] R. Ma, Y. Li, G. Wu, Y. He, J. Feng, Y. Zhao, D. Li, Chin. J. Catal., 2018, 39, 1384-1394.

\title{
水滑石衍生的复合氧化物催化氧化挥发性有机气体的研究进展

\author{
李双德 ${ }^{\mathrm{a}}$, 王东东 ${ }^{\mathrm{a}, \mathrm{b}}$, 武晓峰 ${ }^{\mathrm{a}}$, 陈运法, , , , \\ a中国科学院过程工程研究所多相复杂系统国家重点实验室, 北京100190 \\ b 中国科学院大学, 北京 100049 \\ c中国科学院区域大气环境研究卓越创新中心, 福建厦门361021
}

\begin{abstract}
摘要: 挥发性有机化合物(VOCs) 是大气颗粒污染物 $\left(\mathrm{PM}_{2.5}\right)$ 和臭氧污染的主要前体物, 来源于工业活动(如溶剂使用过程)、 汽车尾气以及植物排放等, 具有毒性, 对人类和自然生命产生危害. 催化氧化技术是在催化剂表面, 在较低的操作温度 $\left(200-450^{\circ} \mathrm{C}\right)$ 下, 将VOCs 非均相催化氧化成 $\mathrm{CO}_{2}$ 和 $\mathrm{H}_{2} \mathrm{O}$, 是一种最为有效的分解VOCs的方法, 具有副产物少, 能耗低的优点. VOCs分解用催化剂主要分为贵金属和金属氧化物两大类. 贵金属催化剂活性高, 但价格昂贵. 因此科研工作者一直在诸 多方面调控过渡金属氧化物, 例如制备方法、组分协同、结构缺陷等, 期望获得高活性、低成本的催化剂.

水滑石 $(\mathrm{LDHs})$ 是一种层状双金属氢氧化物, 由带正电荷的金属氢氧化物层板和层间阴离子组成, 可以表示为 $\left[\mathrm{M}_{1-x}{ }^{2+} \mathrm{M}_{x}^{3+}(\mathrm{OH})_{2}\right]\left(\mathrm{A}^{n-}\right)_{x / n} \cdot m H_{2} \mathrm{O}$. 鉴于LDHs特有的结构特点, 层板元素可调、比例可调等, 其在一定温度下㷽烧可以得到过 渡金属复合氧化物(MMO)材料. 由于LDHs的拓扑焙烧转变得到的MMO材料显示出许多利于多相催化反应的优点, 如大 表面积和多孔性、高热稳定性、良好的金属氧化物分散性等. 水滑石基催化材料用于VOCs催化分解也引起了科研工作者 的持续关注和研究, 文献大多选择苯、甲苯、乙酸乙酯等工业活动中常用的挥发性有机溶剂作为探针分子来评估催化剂的 活性、稳定性等参数. 本综述将LDHs衍生的VOCs降解催化剂分为 4 类, 整理了其近 10 年的研究进展: (1)含过渡金属的 LDHs焙烧转变成MMO催化剂: 系统论述了层板元素组成、层板元素比例、焙烧温度、制备方法等条件对催化活性的影响 规律, 阐明了不同处理条件下催化剂的物理化学特性(比表面积、孔结构、表面元素价态、氧缺陷、还原性)与催化活性的 关联; (2)贵金属/MMO催化剂: 比较了贵金属种类、LDHs载体种类、负载方式等因素对催化活性的影响规律, 总结了贵金 属负载在LDHs载体的优势; (3)核壳型MMO催化剂: 分析了在氧化铝球、MOF等载体上原位负载LDHs的方法构筑多级结 构的MMO催化剂, 利于促进VOCs分解活性; (4)整体型MMO催化剂: 满足VOCs分解实际应用, 提出铝片基底上原位生长煅烧制备高活性位点暴露的整体式催化剂的优点. 在催化活性基础上着重介绍了水蒸气对活性的影响以及VOCs分解催 化机理. 同时提出了3点仍需努力的方向: LDHs向MMO拓扑转变机制认识不足; LDHs衍生的催化剂的VOCs分解机制研 究不深入; 催化剂活性降低-再生研究不透彻.
\end{abstract}

关键词: VOCs氧化; 水滑石; 复合金属氧化物; 水汽; 氧化机理

收稿日期: 2019-09-29. 接受日期: 2019-11-01. 出版日期: 2020-04-05.

*通讯联系人. 电话/传真: ((010)82544896; 电子信箱: yfchen@ipe.ac.cn

基金来源：国家重点研发计划(2017YFC0211503, 2016YFC0207100); 中国科学院战略性先导科技专项A(XDA23030300); 国家自 然科学基金(21401200, 51672273); 多相复杂系统国家重点实验室开放课题(MPCS-2017-D-06); 中国科学院区域大气环境研究卓 越创新中心青年人才项目(CERAE201805).

本文的电子版全文由Elsevier出版社在ScienceDirect上出版(http://www.sciencedirect.com/science/journal/18722067). 